\title{
Chemical Composition and Protective Effect of Rosmarinus officinalis on Alcohol-Induced Serum Hepatic Changes and Liver Injury in Male Rats
}

\author{
Rima Farah AOUAD', Mokhtaria Yasmina BOUFADI ${ }^{2,3, *}$, Djallal Eddine Houari ADLI', Faiza Moulai-Hacene ${ }^{2}$, Khaled \\ KAHLOULA' ${ }^{1}$, Miloud SLIMANI'
}

\section{Rima Farah AOUAD', Mokhtaria Yasmina BOUFADI ${ }^{2,3, *}$, Djallal Eddine Houari ADLI', Faiza \\ Moulai-Hacene ${ }^{2}$, Khaled KAHLOULA ${ }^{1}$, Miloud SLIMANI ${ }^{1}$}

'Laboratory of Biotoxicology, Pharmacognosy and Biological Valorisation of plants (LBPVBP). Department of Biology, Faculty of Natural and Life Sciences, Moulay Tahar University, Saida, ALGERIA.

${ }^{2}$ Laboratory of Bioeconomics, Food Safety and Health, Faculty of Natural Sciences and Life, Université de Abdelhamid Ibn Badis, Mostaganem, ALGERIA.

${ }^{3}$ Laboratory of Pharmaceutical Chemistry, Faculty of Pharmacy, Université Libre de Bruxelles, Brussels, BELGIUM.

\section{Correspondence}

\section{Mokhtaria Yasmina BOUFADI}

Faculty of Natural Sciences and Life Faculty of Natural Sciences and Life Abdelhamid Ibn Badis University, Mostaganem, ALGERIA.

E-mail: yasmina.boufadi@univ-mosta.dz History

- Submission Date: 09-04-2021;

- Review completed: 21-06-2021

- Accepted Date: 28-06-2021.

DOI : 10.5530/pj.2021.13.154

Article Available online http://www.phcogj.com/v13/i5 Copyright

(C) 2021 Phcogj.Com. This is an openaccess article distributed under the term of the Creative Commons Attribution 4.0 International license.

\begin{abstract}
Background: Is a pleasant-smelling perennial shrub that grows in many parts of the world, Rosmarinus officinalis a well known valuable herbal medicine which is widely used in pharmaceuticals and traditional medicine as a digestive, tonic, astringent, diuretic, diaphoretic and useful for urinary ailments. Objective: The objective of this study has, on the one hand, focused on the changes in hepatotoxicity induced by the chronic administration of ethyl alcohol according to a biochemical and histological experimental approach and, on the other hand, on the chemical composition which was determined. As well as, the hepato-protective effect of the ethanolic extract of Rosmarinus officinalis (EER), whether to restore or not the harmful alterations due to ethylism was evaluated. Method: The study included twenty-four male Wistar albino rats which were divided into four groups. The rats received ethanolic extraction of Rosmarinus officinalis orally at a dose of $200 \mathrm{mg} / \mathrm{kg}$. Hepatotoxicity was induced orally with a daily dose of $05 \mathrm{~mL}$ of $20 \%$ alcoholic solution for 90 days. Results: The chemical characterization of the ethanolic extract of Rosmarinus officinalis (EER) by HPLC/UV shows the presence of polyphenolic compounds and numerous flavonoids, the main constituent of which is rosmarinic acid. It was noticed that the Ethanol caused an increase in liver function parameters (aspartate aminotransferase, alanine aminotransferase, alkaline phosphatase, triglyceride and cholesterol, total bilirubin) compared to the control and oxidative stress through a significant decrease in antioxidant liver enzymes Superoxidase dismutase (9.39 U/mg), glutathione peroxidase $(12.89 \mathrm{U} / \mathrm{mg})$ and catalase $(25.39 \mathrm{U} / \mathrm{mg})$ and increased malondialdehyde levels The histological study showed significant lesions in the liver. Conclusion: The disturbances in liver function, antioxidant status and structural damage to the liver caused by ethanol have been restored by the administration of the ethanolic extract of Rosmarinus officinalis which strongly justifies its therapeutic effect. Key words: Rosmarinus officinalis, HPLC/UV, Ethylism, Hepatotoxicity, Liver stress oxidatives.
\end{abstract}

\section{INTRODUCTION}

It is a well-known fact that alcohol is a drink consumed worldwide. ${ }^{1}$ Every year, alcohol abuse is responsible for almost 2.5 million deaths ${ }^{2}$ as it is metabolized by the liver of the human body. Pathological evidence has shown that excessive alcohol consumption is one of the main causes of liver disease and as many as other diseases.,4 Alcohol-induced chronic liver injury passes through several stages, generally develops from alcoholic steatosis to alcoholic hepatitis, and finally deteriorates into alcoholic cirrhosis. ${ }^{5}$

Cirrhosis of the liver is a pathological condition that occurs when chronic liver damage causes scarring of the tissue, preventing blood from flowing freely through the scar tissue. ${ }^{6}$

However, recent work and various other experimental studies have provided strong evidence that oxidative stress plays a key role in ethanol negatively affecting various organs, including the liver. ${ }^{7,8,9}$

The mechanisms leading to cirrhosis are alcohol abuse and chronic liver damage as a result of hepatitis $\mathrm{B}$ or $\mathrm{C}$ infection. We also know that tissue damage resulting from oxidative stress is an important factor in liver failure. ${ }^{10}$
In addition, exposure to ethanol leads to deregulation of fatty acid metabolism and lipid accumulation and causes oxidative stress. ${ }^{11}$ Exposure to ethanol is known to lead to the development of oxidative stress by increasing the production of reactive oxygen species (ROS) or reducing antioxidant defense. ${ }^{12}$

The development of oxidative stress has been proposed as the most important mechanism underlying the lethality and developmental delay associated with ethanol exposure. ${ }^{13}$ At the same time, antioxidant gene expression often increases due to increased production of ROS. ${ }^{14,11,15}$

The oxidative and non-oxidative metabolism of ethanol leads to a considerable increase in the formation of reactive oxygen species (ROS), the $\mathrm{NADH} / \mathrm{NAD}+$ ratio and an accumulation of acetaldehyde inducing the genesis of oxidative stress ${ }^{16}$, which is the cause of several oxidative damages. As well as the formation of fatty acid ethyl esters which are potentially toxic. ${ }^{17}$

Although the precise cellular and biochemical causes of ethanol-induced susceptibility to different lesions have not yet been defined, there is considerable evidence that ethanol-induced oxidative and inflammatory stress plays a critical role in the susceptibility of ethanol to injury ${ }^{18}$, and many ethanol-induced adverse effects can be prevented or 
mitigated by antioxidants. ${ }^{19}$

However, medicinal plants can potentially provide new classes of drugs for pain relief ${ }^{20}$, containing substances that have the ability to protect and/or reduce the damage caused by the ingestion of agents such as ethanol are very useful. ${ }^{21}$

Phenolic compounds found in plants have received particular attention as natural antioxidants. ${ }^{22,23}$ Phenolic compounds are primary antioxidants that act as terminals for free radicals. ${ }^{24}$ In this context, several antioxidant molecules have been proposed as protection against oxidative toxicity. ${ }^{25}$

In folk medicine, the leaves of Rosmarinus officinalis which belong to the Lamiaceae family, known as rosemary, are used as an antispasmodic agent ${ }^{26,27}$ and its maceration in ethanol as a topical agent is prescribed to reduce rheumatic pain in Mexico. Some scientific studies have demonstrated that the ethno-pharmacological use and biological activities of Rosmarinus officinalis, such as antimicrobial ${ }^{28,29}$, anti-tumor, anti-mutagenic and anti-cancer ${ }^{30,31}$, antidepressants ${ }^{32}$, antioxidants ${ }^{28}$, hypoglycemic, hypolipidemic, hypotensive and anti-atherosclerotic properties ${ }^{33,34}$ are quite beneficial. Besides, phytochemical experiments have revealed that the oil of this plant contains terpenoids, flavonoids and alkaloids. ${ }^{34}$ It can be added that Rosmarinus officinalis has produced anti-nociceptive and/or anti-inflammatory effects in some experimental models of pain, including tests of acetic acid-induced contortions and formalin in mice, as well as a model of arthritic pain in rats. ${ }^{35,36}$

The oxidative nature of ethanol, on the one hand, and the protective effect of antioxidant therapy, on the other hand have attempted to design the current work by considering specific underlying molecular mechanisms that may contribute to the adverse effects of ethanol on the liver during ethanol exposure.

Therefore, the objective of this work is focused on the study of the chemical composition of the ethanolic extract of Rosmarinus officinalis (EER) and the evaluation of the in vivo antioxidant power against the effect of ethanol consumption on the liver in male Wistar rats.

\section{MATERIALS AND METHODS}

\section{Vegetable material}

The leaves of Rosmarinus officinalis were harvested in June 2017 during the flowering period, in the north-western region of Algeria (Saida), then dried at room temperature and protected from light, crushed and stored in a glass bottle in the dark.

\section{Preparation of Ethanolic Extract of Rosmarinus officinalis (EER)}

The extraction was done by the maceration method, $10 \mathrm{~g}$ of dried and crushed leaves of Rosmarinus officinalis were dissolved in 100 $\mathrm{mL}$ of $99.8 \%$ ethanol, protected from light and at room temperature for three days under sonication for $90 \mathrm{~min}$ each day to extract the active ingredients, then filtration was carried out on Whatman $\mathrm{N}^{\circ} 1$ paper before evaporation of the solvent under reduced pressure at a temperature of $55^{\circ} \mathrm{C}$ by a rotavapor. The powder obtained represents the dry ethanolic extract of Rosmarinus officinalis (EER) and was stored at $4^{\circ} \mathrm{C}$ in tinted glass vials until use.

\section{Chemical composition by HPLC/UV}

The chromatographic analysis of the ethanolic extract of Rosmarinus officinalis (EER) was performed on a high performance liquid chromatography (Agilent 1100). Separation was performed on an Agilent poroshell120EC column $(100 \mathrm{~mm} \times 2.1 \mathrm{~mm}, 2.7 \mathrm{~m})$, using mobile phases: water /TFA/ formic acid (99: 0.25: 0.75) (A) and acetonitrile (B). Elution was performed at a flow rate of $0.6 \mathrm{~mL} / \mathrm{min}$ with an aliquot of $10 \mu \mathrm{L}$ and at a temperature of $55^{\circ} \mathrm{C}$. Using a gradient method as follows $(\mathrm{t} / \mathrm{min}, \% \mathrm{~B}):(0,0),(1,10),(2,12.5),(3,15),(9$, $80),(10,100),(11,100),(14,0)$ with post $5 \mathrm{~min}$. Chromatograms were recorded at 270 and $320 \mathrm{~nm}$. The sample was prepared by diluting the ethanolic extract of Rosmarinus officinalis (EER) with methanol at 1:100 (w / v). The components of the ethanolic extract of Rosmarinus officinalis (EER) were identified by comparing their retention times and UV spectra with different commercial phenolic standards (transcinnamic, gallic acid, benzoic acid, ferulic acid), m-coumaric acid, caffeic acid, rosmarinic acid and ellagic acid), flavonoids (catechin, hesperidin, thymol, galan-gin, tectochrysin, pinocembrin, acetine, rutin, chrysine, apigenin, kaempferol and quercetin) and other compounds (ascorbic acid, menthol). The standards were dissolved in methanol to give stock solutions at $1 \mathrm{mg} / \mathrm{mL}$. The quantification of the constituents was determined using standard curves expressed in $\mathrm{mg}$ per $1 \mathrm{~g}$ of powder of ethanolic extract of Rosmarinus officinalis (EER).

\section{Dosing of Total Polyphenols and Flavonoids}

The quantification of polyphenols in the ethanolic extract of Rosmarinus officinalis (EER) was determined by the colorimetric method of FolinCiocalteu. ${ }^{37}$

$40 \mu \mathrm{L}$ extract is mixed with $1.5 \mathrm{~mL}$ Folin-Ciocalteu reagent (10\%) and $1.5 \mathrm{~mL}$ sodium carbonate $\left(\mathrm{Na}_{2} \mathrm{CO}_{3}\right)(7.5 \%)$. Then add up $100 \mathrm{~mL}$ with distilled water. Allow the reaction medium to stand for 30 minutes at room temperature and protect it from light $\mathrm{f}$. Reading is performed with a spectrophotometer (UV mini-1240) at $760 \mathrm{~nm}$. A calibration curve is performed in parallel under the same conditions using gallic acid at different concentrations. The results are expressed in milligram equivalent of gallic acid per gram of extract (mg GAE/g).

The flavonoid content is determined according to the $\mathrm{AlCl}_{3}$ aluminum trichloride method described by Woisky and Salatino ${ }^{38}$, which consists of mixing $1 \mathrm{~mL}$ of extract with $1 \mathrm{~mL}$ of $2 \%(\mathrm{~W} / \mathrm{V}) \mathrm{AlCl}_{3}$ solution and allowing it to react for $30 \mathrm{~min}$ before reading the absorbance against a blank at $430 \mathrm{~nm}$.

A calibration curve with quercetin is established under the same reaction conditions as the sample with distilled water instead of the extract. The flavonoid content is expressed in milligram quercetin equivalent per gram extract (mg EQ/g extract).

Evaluation of the antioxidant activity by the method of reduction of the free radical of 2,2-diphenyl-1picrylhydrazyl (DPPH)

The anti-radical power of the ethanolic extract of Rosmarinus officinalis (EER) was determined by the colorimetric method using the chemical complex 2,2-diphenyl-1-picrylhydrazyl (DPPH). $200 \mu \mathrm{L}$ of ethanolic extract of Rosmarinus officinalis at different concentrations100, 250, 500 and $1000 \mu \mathrm{g} / \mathrm{mL}$ are added to $2.8 \mathrm{ml}$ of the DPPH solution $(60$ $\mu \mathrm{M})$. After $30 \mathrm{~min}$ incubation in the dark and at room temperature, the absorbance reading is taken at $515 \mathrm{~nm}$.

The free radical scavenging activity of the extract was calculated as a percentage inhibition according to the following formula:

[\%RSA $=($ Abs C - Abs E)/ Abs C x 100].

Abs C: Absorbance of control.

Abs E: Absorbance of the extract.

The antioxidant activity was expressed by the IC50, defined as the concentration of the extract causing a $50 \%$ decrease in the initial concentration of DPPH. 


\section{Animals and accommodation conditions}

Twenty-four (24) male Wistar Albino rats (100 to $110 \mathrm{~g}$ ) supplied by the Pasteur Institute of Algiers (Algeria) were used. The protocol is in accordance with the guidelines of the National Institute of Health (NIH-USA).

Upon receipt, the rats were randomly divided into 4 experimental groups, each containing 6 rats, and were subjected to a two-week adaptation period at room temperature and a $12 / 12 \mathrm{~h}$ photoperiod. The rats were given free access to food and water.

\section{Experimental protocol}

The first group was used as a negative control (G1); (G2) Group 2 rats received $5 \mathrm{~mL}$ of ethanol orally for 90 days, G3 received $200 \mathrm{mg} / \mathrm{kg}$ of ethanolic extract of Rosmarinus officinalis (EER) orally for 90 days; G4 was administered $200 \mathrm{mg} / \mathrm{kg} /$ day of EER and $5 \mathrm{~mL} /$ day of ethanol at the same time for 90 days.

At the end of the experiment, the rats are fasted for 12 hours before blood collection. In order to avoid any risk of changing biochemical parameters by administering general anesthesia, the animals were kept under a light chloroform anesthesia before being euthanized just before the blood samples were collected. Serum samples were obtained from the dry tubes, while plasma samples were obtained from the heparinized tubes.

The liver was recovered and rinsed with physiological water. Part of the liver was fixed in formalin for the histological study, the second part was placed in PBS buffer (10 mM PO43-/300 mM NaCl, pH 7.4). The preparation of the liver tissue homogenate was done according to the protocol of Tang ${ }^{39}$ cited by Chaa ${ }^{40}$. Homogenize the second part of the liver pieces in ice buffer $(250 \mathrm{mM}$ sucrose, $10 \mathrm{mM}$ Tris - $\mathrm{HCl}$, $0.5 \mathrm{mM}$ EDTA and $0.5 \%$ bovine serum albumin, $\mathrm{pH} 7.4$ ), recover the supernatant by centrifugation at $112 \mathrm{x}$ g for $15 \mathrm{~min}$ at $4^{\circ} \mathrm{C}$. Repeat this procedure twice, in order to place the mitochondrial pellet in PBS

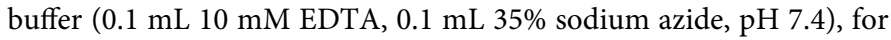
various assays.

\section{Determination of biochemical parameters of liver function}

The assay of the activity of aspartate aminotransferase (AST, EC 2.6.1.1) and alanine aminotransferase (ALT, EC 2.6.1.2) was determined using bio-Merieux kits (bioMerieux SA France). The activity of alkaline phosphatase (ALP, EC 3.1.3.1) and gamma-glutamyl transferase ( $\gamma$ GT; EC 2.3.2.2) was performed with kits from Spinreact (Spinreact, Spain). The total bilirubin assay was performed with the BIOLABO kit (BIOLABO SA, France). The lipid balance (triglyceride and cholesterol) was performed with the Human kits (Human, Germany).

\section{Measurement of antioxidant markers in the liver}

The determination of superoxide dismutase activity in liver tissue was carried out by the protocol of Elster. ${ }^{41}$ The determination of the enzymatic activity of catalase in liver homogenate was carried out by the method of Lück ${ }^{42}$ and Aebi. ${ }^{43}$ GPx activity was measured by the method of Paglia and Valentine. ${ }^{44}$ Malondialdehyde (MDA) was measured according to the method described by Yagi. ${ }^{45}$

\section{Anatomopathological study of the liver}

Blocks of liver portions preserved in $10 \%$ formalin were put in kerosene which were then cut with a rotating microtome (Leica, Germany) at $5 \mu \mathrm{m}$ thick. The resulting sections were spread on microscope slides and stained with hematoxylin and eosin, and observed with an optical microscope. ${ }^{46}$

\section{Statistical analyses}

Sigma Stat software (SPSS, 3.0, SPSS, Inc., Chicago, IL, USA) was used for the statistical analysis. The data are presented as mean \pm standard deviation and were evaluated by ANOVA, using Dunnett's posthoc test. The in Vivo study experiment was independently repeated 6 times in a fully randomized design. The in vitro experiments were independently repeated 3 times in a fully randomized device. The difference is considered significant at $\mathrm{P}<0.05$.

\section{RESULTS}

\section{Chemical composition of the EER extract}

The extraction of the ethanolic extract of Rosmarinus officinalis (EER) by maceration with ethanol (99.8\%) from the powder of the leaves of the plant reveals that the ethanolic extract (EER) contains a yield of $18.5 \%$.

The chromatograms obtained by HPLC/UV at 270 and $320 \mathrm{~nm}$ of the ethanolic extract of Rosmarinus officinalis (EER) are shown in Figures $1 \mathrm{~A}$ and $\mathrm{B}$, respectively. We were able to identify 23 phenolic compounds, of which the main flavonoids of the ethanolic extract of EER are; quercetin, catechin, luteolin and chrysin, with a content of $11.94,9.56,7.34$, and $6.33 \mathrm{mg} / \mathrm{g}$ EER, respectively. In addition, the highest phenolic acid content was recorded in rosmarinic acid and gallic acid (11.85 and $7.46 \mathrm{mg} / \mathrm{g}$ EER, respectively). Ellagic acid and tannic acid were found at low concentrations (Table 1).

\section{Phenolic compound content of Rosmarinus officinalis}

The results summarized in Table 2 show that the phenolic content of the EER ethanolic extract is $223.25 \mathrm{mg}$ EAG/g EER while the flavonoid content is $83.7 \mathrm{mg} \mathrm{EQ} / \mathrm{g}$ EER.

Evaluation of the anti-radical power and the lipoperoxidation inhibition activity of the EER extract

The scavenging results of the DPPH free radical and the lipid peroxidation inhibitory power of the EER ethanolic extract are presented in Table 2 .

The results show that the extract of Rosmarinus officinalis has a very important anti-free radical activity. The EER ethanolic extract had an $\mathrm{IC}_{50}=159.53 \mu \mathrm{g} / \mathrm{mL}$ whereas, the $\mathrm{IC}_{50}$ for the inhibition of lipid peroxidation is of the order of $29.03 \pm 0.23 \mu \mathrm{g} / \mathrm{mL}$.

\section{Evaluation of biochemical parameters of liver function}

Several hepatic parameters were measured to evaluate the therapeutic effect of the ethanolic extract of Rosmarinus officinalis on hepatotoxicity induced by chronic ethylism. Table 3 shows these hepatic parameters.

Compared to rats in the negative control group, ethanol increased serum levels of liver function namely; aspartate aminotransferase, alanine aminotransferase, total bilirubin, total protein and albumin in G2 rats. There was a significant $(\mathrm{P}<0.05)$ decrease in these parameters in Group G3 and G4 rats who received $200 \mathrm{mg} / \mathrm{kg} /$ day of EER and 200 $\mathrm{mg} / \mathrm{kg} /$ day of EER followed by $5 \mathrm{~mL}$ of ethanol for 90 days, respectively, compared to Group G1 rats.

In addition, rats receiving ethanol (G2) showed increased serum concentrations of triglycerides, cholesterol, gamma glutamyl transferase and alkaline phosphatase, $(\mathrm{P}<0.05)$ compared to the $\mathrm{G} 1$ group, while the concentrations of the latter in rats treated with $200 \mathrm{mg} /$ $\mathrm{kg} /$ day of EER were reduced. Administration of EER in combination with ethanol in group $G 4$ showed a very significant $(P<0.05)$ decrease in these liver parameters compared to group G2. 

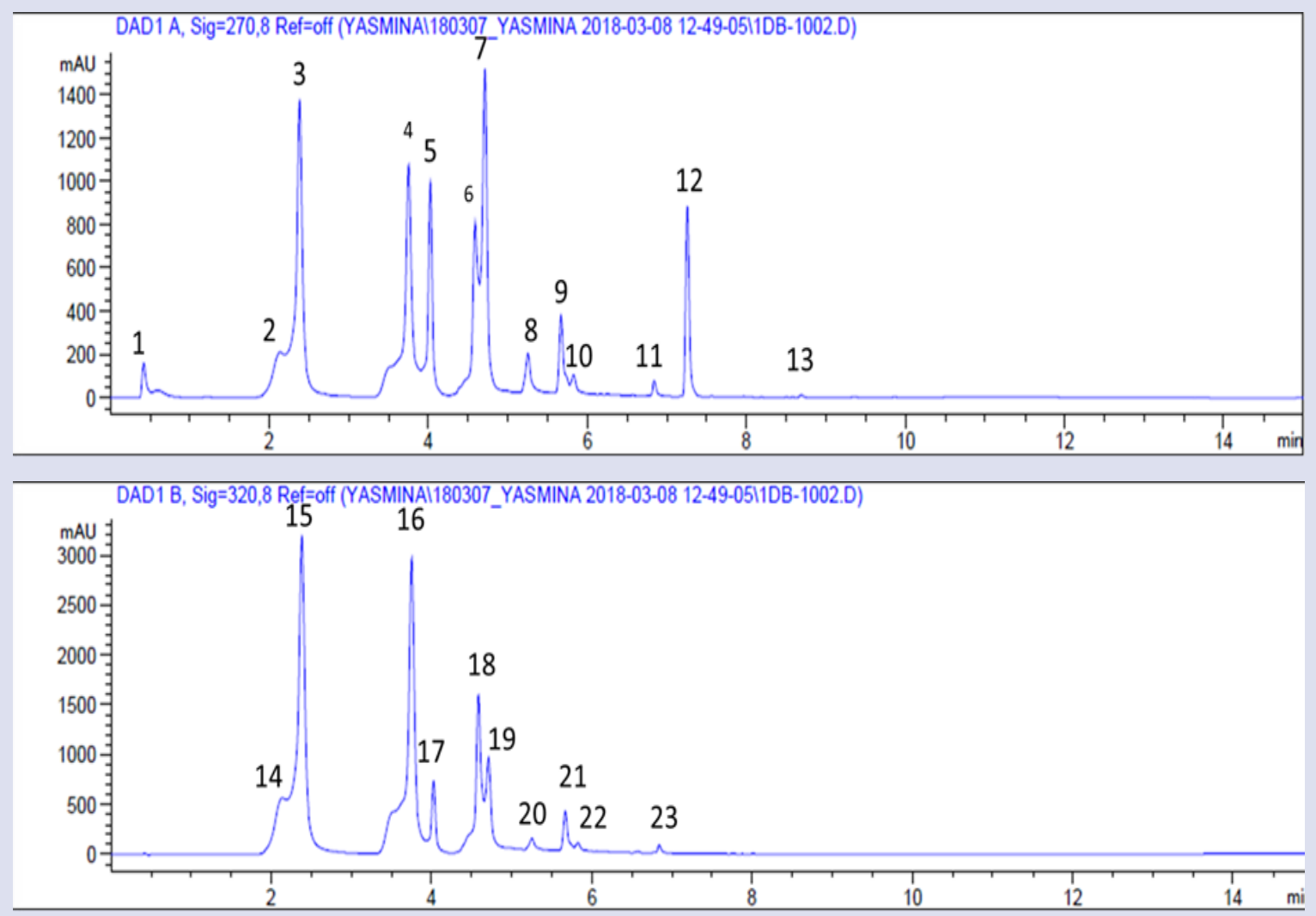

Figure 1: Chromatograms by HPLC/UV analysis of EER at a wavelength of 270 (A) and $320 \mathrm{~nm}$ (B): 1-Galangin 2- Epicatechin 3- Catechin 4-Luteolin 5- Kaempferol 6- Bis methylated quercentin 7-quercetin 8 - Pinocembrin 9- Carnosol 10- Myricetin 11-Menthol 12-Chrysin 13-Thymol 14-Syringic acid 15- Rosmarinic acid 16-Gallic acid 17-Trans cinnamic 18- Caffeic acid 19- Carnosic acid 20-ascorbic acid 21-Ferrulic acid 22 - Tannic acid 23-Ellagic acid Phenolic compound content of Rosmarinus officinalis.

Table 1: Composition of Rosmarinus officinalis ethanolic extract (EER) by HPLC/UV (mg/g).

\begin{tabular}{|c|c|c|c|}
\hline Peak number & Compound & Retention time (min) & Amount (mg/g EER) \\
\hline 1 & Galangin & 0.19 & 0.58 \\
\hline 2 & Epicatechin & 0.17 & 2.13 \\
\hline 3 & Catechin & 9.56 & 2.37 \\
\hline 4 & Luteolin & 7.34 & 3.74 \\
\hline 5 & Kampferol & 0.79 & 4.02 \\
\hline 6 & Bis-methylated quercetin & 5.05 & 4.58 \\
\hline 7 & Quercetin & 11.94 & 4.71 \\
\hline 8 & Pinocembrin & 0.93 & 5.25 \\
\hline 9 & Carnosol & 1.96 & 5.66 \\
\hline 10 & Myricetin & 0.15 & 5.82 \\
\hline 11 & Menthol & 0.11 & 6.84 \\
\hline 12 & Chrysin & 6.33 & 7.25 \\
\hline 13 & Thymol & 0.06 & 8.68 \\
\hline 14 & Syringic acid & 1.32 & 2.13 \\
\hline 15 & Rosmarinic acid & 11.85 & 2.37 \\
\hline 16 & Gallic acid & 7.46 & 3.74 \\
\hline 17 & Trans cinnamic & 1.80 & 4.02 \\
\hline 18 & Caffeic acid & 3.66 & 4.58 \\
\hline 19 & Carnosic acid & 2.89 & 4.71 \\
\hline 20 & Ascorbic acid & 0.22 & 5.25 \\
\hline 21 & Ferrulic acid & 1.43 & 5.66 \\
\hline 22 & Tannic acid & 0.15 & 5.82 \\
\hline 23 & Ellagic acid & 0.09 & 6.84 \\
\hline
\end{tabular}


Table 2: Concentrations of total polyphenols and flavonoids, inhibition of lipoperoxidation and anti-radical activity, of the ethanolic extract of Rosmarinus officinalis (EER).

\begin{tabular}{|lllll}
\hline Fraction & $\begin{array}{l}\text { Total Polyphenols } \\
(\mathrm{mg} \text { EAG/g of EER) }\end{array}$ & $\begin{array}{l}\text { Flavonoids } \\
(\mathrm{mg} \text { EQ/g of EER) }\end{array}$ & Anti-radical IC $\mathrm{F}_{50}(\mu \mathrm{g} / \mathrm{mL})$ & $\begin{array}{l}\text { Inhibition of } \\
\text { lipoperoxidation } I C_{50}(\mu \mathrm{g} / \\
\mathrm{mL})\end{array}$ \\
\hline Extract (EER) & $223.25 \pm 4.03$ & $83.7 \pm 5.95$ & $159.53 \pm 9.67$ & $29.03 \pm 0.23$
\end{tabular}

The values are expressed as mean \pm SD $(n=3)$.

Table 3: Effect of ethanolic extract of Rosmarinus officinalis (EER) on hepatic function parameter values of Wistar rats exposed to ethanol.

\begin{tabular}{lcccc}
\hline Parameter & G1 & G2 & G3 & G4 \\
\hline ALAT (UI/l) & $39.48 \pm 0.98$ & $141.33 \pm 3.72$ & $40.98 \pm 0.88$ & $53.5 \pm 4.59$ \\
ASAT (UI/l) & $52.56 \pm 1.69$ & $158.16 \pm 5.98$ & $45.16 \pm 4.16$ & $53.5 \pm 4.59$ \\
Bil T (mg/l) & $4.3 \pm 0.42$ & $8.05 \pm 0.34$ & $4.40 \pm 0.34$ & $5.73 \pm 0.36$ \\
Prot T (g/l) & $72.63 \pm 2.38$ & $43.60 \pm 5.16$ & $73.45 \pm 2.91$ & $67.15 \pm 2.48$ \\
ALB (g/l) & $37.5 \pm 2.25$ & $20.83 \pm 2.40$ & $41 \pm 2.44$ & $33.33 \pm 1.63$ \\
TG (g/l) & $0.43 \pm 0.13$ & $1.9 \pm 0.16$ & $0.4 \pm 0.11$ & $0.55 \pm 0.66$ \\
CH(g/l) & $1.52 \pm 0.18$ & $2.01 \pm 0.04$ & $1.50 \pm 0.05$ & $1.84 \pm 0.08$ \\
-GT(UI/l) & $29.18 \pm 1.09$ & $114.33 \pm 6.47$ & $28.19 \pm 01.81$ & $34.38 \pm 0.08$ \\
PAL(UI/l) & $81.50 \pm 1.64$ & $425.45 \pm 04.28$ & $80.51 \pm 02.33$ & $111.5 \pm 08.78$
\end{tabular}

The values are expressed as mean $\pm S D(n=6)$.

*Significant difference from the control group $(p<0.05) . * *$ Significant difference from the ETH hepatotoxicity group $(p<0.05)$.

Table 4: Effect of ethanolic extract of Rosmarinus officinalis (EER) on malondialdehyde (MDA), superoxide dismutase (SOD), catalase (CAT) and glutathione peroxidase (GSH-Px), in the liver of Wistar rats exposed to ethanol.

\begin{tabular}{lcccc}
\hline Parameter & G1 & G2 & G3 & G4 \\
\hline $\begin{array}{l}\text { MDA liver } \\
\text { (nmol/ml) }\end{array}$ & $2.38 \pm 0.05$ & $9.835 \pm 0.35$ & $2.11 \pm 0.0$ & $2.25 \pm 0.09$ \\
$\begin{array}{l}\text { SOD liver } \\
\text { (U/cg Hb) }\end{array}$ & $44.78 \pm 1.87$ & $9.39 \pm 1.21$ & $76.31 \pm 1.42$ & $44.36 \pm 1.55$ \\
$\begin{array}{l}\text { CAT liver } \\
\text { (U/mg Hb) }\end{array}$ & $112.71 \pm 3.58$ & $25.39 \pm 1.80$ & $125.77 \pm 1.99$ & $111.88 \pm 3.58$ \\
$\begin{array}{l}\text { GSH-Px liver } \\
\text { (U/g Hb) }\end{array}$ & $125.03 \pm 1.73$ & $12.89 \pm 0.68$ & $508.83 \pm 22.49$ & $121.24 \pm 1.68$
\end{tabular}

The values are expressed as mean \pm SD $(n=6)$.

*Significant difference from the control group $(p<0.05) . * *$ Significant difference from the ETH hepatotoxicity group $(p<0.05)$.

\section{Assessment of oxidative status in the liver}

Table 4 shows the level of malondialdehyde (MDA) and enzymes (superoxide dismutase, catalase and glutathione peroxidase) related to oxidative stress status in the liver tissues of the different groups. These results indicate that ethanol (G2) decreased antioxidant enzyme activities (SOD, CAT and GPx) at levels of $-73,-70$ and $-88 \%$ respectively in the liver. In addition, the level of lipid peroxidation in the liver was significantly increased $(9.83 \mathrm{nmol} / \mathrm{mL})$ in the group that received only ethanol (G2) compared to the $\mathrm{G} 1$ group $(2.38 \mathrm{nmol} / \mathrm{mL})$. In contrast, rats in G3 (treated with $200 \mathrm{mg} / \mathrm{kg} /$ day of EER) and G4 (treated with $200 \mathrm{mg} / \mathrm{kg}$ of EER and $5 \mathrm{~mL} / \mathrm{kg} /$ day of ethanol) showed an increase in liver antioxidant status parameters (SOD, CAT and GPx) and a reduction in MDA levels.

\section{Anatomopathological study of liver tissue}

The histological study of the liver of rats in the negative control group (G1) shows a normal architecture of the hepatic parenchyma, with sinusoids and a centrolobular vein that are essentially normal (Fig. 2A).

The histological structure (Fig. 2D) of the liver of rats treated exclusively with the ethanolic extract of Rosmarinus officinalis (EER) (G3) revealed a similar architecture to that observed in the control group (G1).

Nevertheless, since the histological section of figure 2 (B,C) refers to G2, (rats intoxicated with ethanol), the biopsy showed a variety of major hepatic lesions, severe mixed (micro and macro vacuolar) steatosis, congestion of portal veins and sinusoid capillaries, portal and lymphocytic type inflammatory reaction in the sinusoid capillaries and hepatocytic necrosis.

Treatment of rats with $200 \mathrm{mg} / \mathrm{kg} /$ day of ethanolic extract of Rosmarinus officinalis (EER) showed a liver with normal architecture with a discrete focus of mixed steatosis, discrete sinusoidal congestion with the presence of some inflammatory elements in the sinus capillaries (Fig. 2E,F).

\section{DISCUSSION}

The phytochemical profile established by HPLC/UV of ethanolic extract of Rosmarinus officinalis has led to the identification and quantification of numerous bioactive components with various pharmacological properties, belonging to different classes of constituents, the majority of which are mainly rosmarinic acid.

The chemical composition of our extract differs qualitatively and quantitatively from that previously analyzed by Amaral $^{47}$, which revealed the presence of chlorogenic acid $(12.2 \mathrm{mg} / \mathrm{g})$, caffeic acid $(7.63 \mathrm{mg} / \mathrm{g})$, rutin $(3.07 \mathrm{mg} / \mathrm{g})$, rosmarinic acid $(38.5 \mathrm{mg} / \mathrm{g})$, quercetin (5.10 mg / g), kaempferol (2.53 mg / kg) and carnosic acid (26.4 mg / g). However, rosmarinic acid and carnosic acid are the main majority constituents found in our extract and the one analyzed by Amaral. ${ }^{47}$

The results obtained show that EER extract is rich in polyphenols and flavonoids. These results are eminent to those obtained by Menaceur ${ }^{48}$, whose polyphenol content of the ethanolic extract of EER is $195.24 \mathrm{mg}$ $\mathrm{EAG} / \mathrm{g}^{49}, 128.97 \mathrm{mg} \mathrm{EAG} / \mathrm{g}^{50}, 04.99 \mathrm{mg} \mathrm{EAG} / \mathrm{g}^{51}$, and $162 \mathrm{mg} \mathrm{EAG} /$ mg reported by Ho. ${ }^{52}$ The flavonoid concentration of $20.1 \mathrm{mg} \mathrm{EQ} / \mathrm{g}$ 


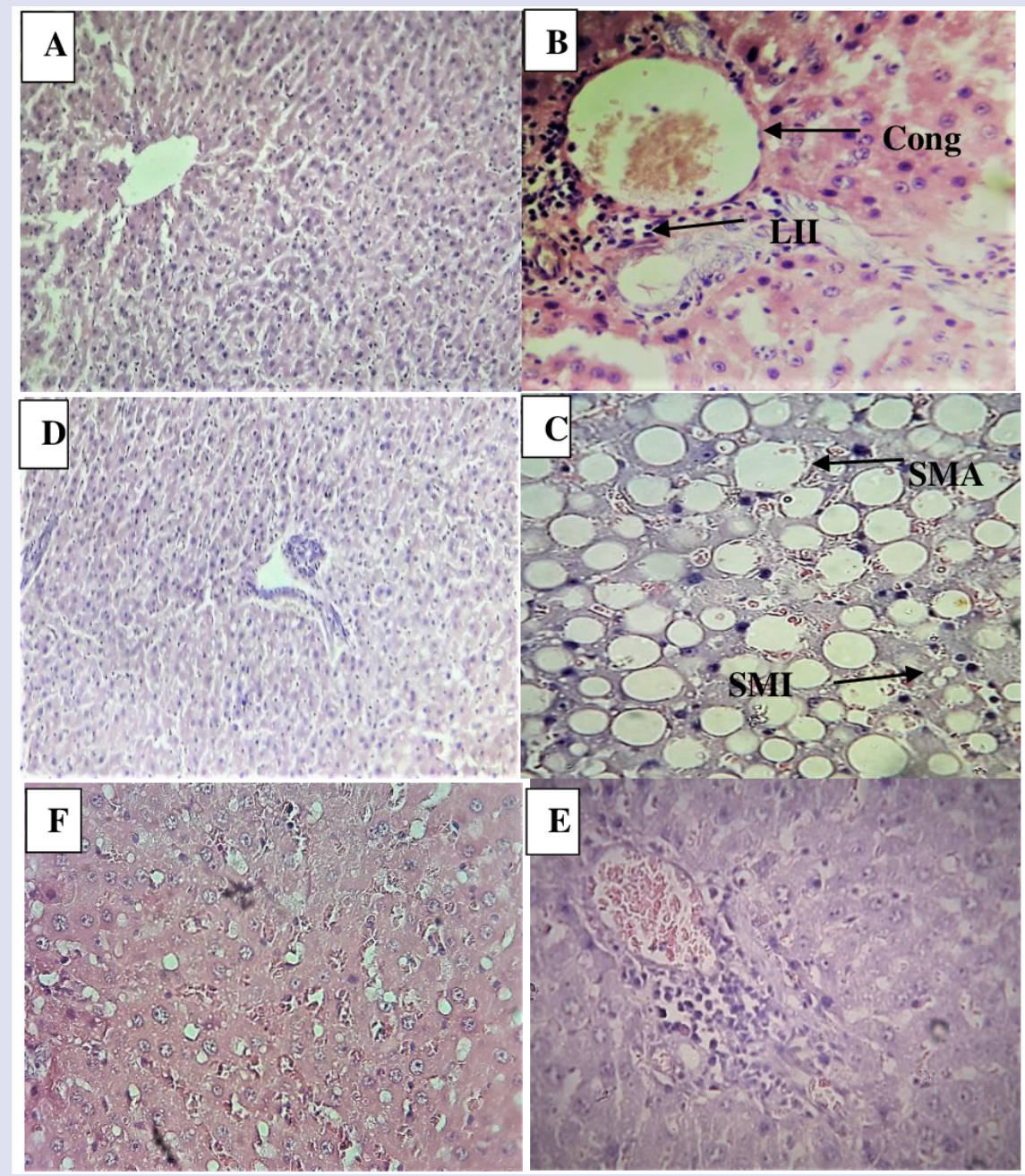

Figure 2: Histological cuts of rat's liver of groups: G1 (A); G2 (B,C); G3 (D); G4 (E,F). Abbreviations: Cong: congestion, Lll: lymphocytic inflammatory infiltrate SMA: macrovacuolar steatosis, SMI: microvacuolar steatosis.

remains lower than that found in our extract, on the other hand, the one reported by $\mathrm{Tsai}^{53}$ is close to $60.7 \mathrm{mg} \mathrm{EQ} / \mathrm{g}$ EER.

The contents of phenolic compounds vary qualitatively and quantitatively within the same plant as well as from one plant to another, this can be explained by the variation in the distribution and content of secondary metabolites during plant growth due to intrinsic and extrinsic factors. ${ }^{54,55}$

In addition, many factors discovered by Wang ${ }^{56}$, Koşar ${ }^{57}$, Durling ${ }^{58}$ related to climatic and environmental conditions (high temperature, solar exposure, drought, salinity), which stimulate the biosynthesis of secondary metabolites such as polyphenols, also depend on the time of harvest, geographical location, extraction solvent, its polarity ${ }^{59,60}$, storage conditions and duration. ${ }^{61,58}$

We have noted that there is a correlation between the concentration of polyphenols and antioxidant activity, indicating that the ethanolic extract of Rosmarinus officinalis has a high antioxidant activity capable of inhibiting the formation of free radicals and opposing the oxidation of macromolecules ${ }^{62}$, due to its richness in phenolic compounds mainly rosemary acid ${ }^{63}$, which is the current major phenolic component in rosemary extract. ${ }^{64,65}$

Rosemary extract is rich in phenolic compounds mainly rosmarinic acid and flavonoids, which could play an important role in the defense system as they are recognized as excellent antioxidants. ${ }^{66}$ This could explain the antioxidant property of EER, which has enabled the protection of the liver against disasters generated by alcohol metabolism.

However, it is rather difficult to attribute the therapeutic effect of an extract to one or a few active ingredients, as extracts always contain a mixture of different bioactive chemical constituents. ${ }^{67,68}$ What's more, the main constituents, minor compounds can make a significant contribution to the pharmacological activity of extracts.

According to Erkan ${ }^{51}$; scavenging of the DPPH radical revealed a very eminent antiradical power of the ethanolic extract of rosemary, presenting an $\mathrm{IC}_{50}$ of $54 \mu \mathrm{g} / \mathrm{mL}$, which is three times less than that shown in our study. In addition, results reported by other researchers have also shown that this parameter is variable in the antiradical activity of rosemary, Wojdyło ${ }^{69}$ found an $\mathrm{IC}_{50}$ of around $513 \mu \mathrm{g} / \mathrm{mL}$.

With regard to the improvement of the various biomarkers of liver function and the maintenance of liver structural integrity following the administration of ethanolic extract of Rosmarinus officinalis in intoxicated rats, EER extract has a free radical scavenging activity as determined by the DPPH test and peroxidation inhibition.

Serum analysis revealed a dysfunction of liver parameters following chronic exposure to ethanol for 90 days in rats.

Hypertriglyceridemia and hypercholesterolemia was observed in G2 intoxicated rats, which is consistent with the study in rhesus monkeys 
which revealed that ingestion of ethanol for 3 months resulted in an accumulation of triglycerides, cholesterol and phospholipids in serum and liver. ${ }^{70}$ These results show that ethyl alcohol is the cause of lipid metabolic disturbances, a consequence of the oxidation of ethanol is the increase in the NADH/NAD+ ratio which leads to a disturbance of carbohydrate and lipid metabolism ${ }^{71}$, which explains the observation of cholesterol accumulation in the liver and an increase in plasma LDL and HDL in alcoholic liver disease. ${ }^{72}$

The ethanolic extract of EER provides a hepatoprotective effect, which is consistent with the work of Sotelo-Félix ${ }^{73}$ who showed that Rosmarinus officinalis partially limited the inflammation and necrosis induced by $\mathrm{CCl}_{4}$ carbon tetrachloride in rats and other research has shown that methanolic extracts of rosemary could also inhibit lipid peroxidation in the liver of $\mathrm{CCl}_{4}$-treated rats. The extract of Rosmarinus officinalis has an antioxidant effect via the inhibition of lipoperoxidation. ${ }^{74,75}$

Rosemary exerts beneficial effects on the treatment of alcoholic hepatotoxicity by modulating the hepatic oxidative state through the trapping of harmful free radicals, but also through the activation and induction of the enzymatic mechanisms of physiological defense ${ }^{76}$ and immune stimulation ${ }^{77}$ which limits the extent of lipid peroxidation and thus the preservation of cell membranes and/or intracellular hepatocyte membranes in the liver tissue of animals, or may act directly on the process of transformation of ethanol into secondary metabolites in the animal organism by increasing its clearance, which may be another possible mechanism of action. This has been shown to inhibit and slow the onset of alcoholic liver disease.

The metabolism of alcohol, which damages mainly the liver, is characterized by the generation of free radicals and reactive oxygen species. In addition, the main pathway for the metabolism of alcohol involves the enzyme alcohol deshydrogenase (ADH).

The increase in serum liver enzymes can be attributed to hepato cytolysis of the structural integrity of the liver by alteration of the extracellular and intracellular membranes of hepatocytes reflecting cellular necrosis induced by the toxic metabolism of ethyl alcohol, leading to elevated levels in plasma. ${ }^{78,79}$

Rats exposed to ethyl alcohol showed a significant increase in bilirubin levels compared to control rats (G2). This increase in the bilirubin level is in favour of an alteration in the excretory function of the liver following a defect in elimination by the hepatocyte, which is a sign of liver damage caused by chronic ethyl alcohol intoxication. Studies have shown that necrotizing toxicants generate lesions of the hepatic parenchyma inducing an increase in the concentration of bilirubin in the serum..$^{80}$

Studies have shown that chronic alcohol consumption alters both enzyme levels and non-enzymatic endogenous antioxidant systems. The result is oxidative stress with a cascade of effects, affecting the functional and structural integrity of cell membranes and organelles responsible for the genesis of different forms of alcohol-induced liver disease. ${ }^{14}$

In our study, exposure to ethanol for 90 days significantly reduced antioxidant enzymes in the liver. This reduction is promoted by the production of oxidative stress which is characterized by the generation of toxic acetaldehyde and other reactive molecules in the cell, reflecting the pathological effect of ethanol metabolism on antioxidant status compared to the control group. The reduction in the activities of these antioxidant enzymes may be due to inhibition of their synthesis or could also result from the oxidation of enzyme proteins by the generation of reactive oxygen species during ethanol metabolism.

The induction of oxidative stress by alcohol metabolism was clearly reversed by therapy with ethanolic extract of Rosmarinus officinalis at a dose of $200 \mathrm{mg} / \mathrm{kg} /$ day with the observation of increased reduced levels of SOD, CAT and GSH-PX in rats in the group treated with ethanol and EER extract compared to the group receiving ethanol alone.

The improvement in the activities of defense enzymes in the liver of alcoholic rats receiving a diet of EER extract, confirms the hypothesis that EER has a restorative effect in the antioxidant status in alcoholic rats and protected the liver from the deleterious effect of oxidative stress generated by ethanol responsible for its toxicity.

These changes are probably due to the combined protective effects of the bioactive chemical components of the EER extract and an increase in the transcription of the enzyme-encoding gene, as it has been reported that genes encoding phase II enzymes are strongly induced by antioxidant compounds..$^{81,82}$

The ethanolic extract of EER, which showed strong lipoperoxidation inhibition activity with a 50\% enzyme activity inhibition concentration $\left(\mathrm{IC}_{50}\right)$ of $29.03 \mu \mathrm{g} / \mathrm{mL}$ at an administered dose of $200 \mathrm{mg} / \mathrm{kg} /$ day, caused a very marked reduction in hepatic MDA levels in treated rats compared to alcohol intoxicated rats.

The blockage of lipid peroxidation by Rosmarinus officinalis may be due to According to the established reports of Kumar and Kutan ${ }^{83}$ and Khatoon ${ }^{84}$ to the set of antioxidant bioactive compounds present in the plant extract that inhibit the oxidation of macromolecules.

This protection generated by the ethanolic extract of Rosmarinus officinalis is probably due to its antioxidant and anti-lipoperoxidant effect without excluding the possible intervention of other pharmacological properties of the various metabolites contained in the ethanolic extract of EER.

Lipid peroxidation, an index of oxidative stress originating from free radicals in vivo, is a process during which the polyunsaturated fatty acids constituting membrane phospholipids are converted into lipoperoxides. This results in a considerable alteration of the structure and functions of cellular and subcellular membranes; it is often characterized by a high concentration of malondialdehyde (MDA) ${ }^{85}$

MDA in liver homogenate was determined as lipid Peroxidation Index. ${ }^{86}$ The observed high level of MDA in the liver could cause the generation of free radicals leading to membrane lipid peroxidation involved in the pathogenesis of liver damage due to chronic alcohol intoxication by altering the structure and functions of cellular and subcellular membranes. ${ }^{87}$

Ethyl alcohol is the most toxic component of alcoholic beverages; its long-term ingestion evokes multiple variations in cellular functions and the oxidant/antioxidant system affecting several organs such as: liver, brain, kidney, and pancreas. It is absorbed in the stomach and intestine. ${ }^{21,88}$

These changes observed in the various liver biomarkers are indicative of the presence of tissue damage; this was confirmed by the histological study of the liver of rats exposed to ethyl alcohol, which revealed an intense distortion of the liver architecture. Hepatic cells, intra-lobular veins and endothelium were found to be damaged with a variety of major hepatic lesions including severe mixed steatosis (micro and macro vacuolar), congestion of portal veins and sinusoid capillaries, portal and lymphocytic type inflammatory reaction in the sinusoid capillaries and hepatocytic necrosis.

These tissues and cellular alterations revealed a toxic hepatopathyresul which resulted from long-term treatment with ethyl alcohol, whose hepatic lesions are the result of a complex process involving multiple mechanisms initiated by the toxicity of its metabolite acetaldehyde and other reactive species generated by the induction of CYP2E1. This was at the origin of the genesis of hepatocyte oxidative stress, which is responsible for lipid peroxidation, thus participating in the architectural disorganization of cell membranes. 
The results obtained showed that chronic alcohol intoxication leads to a reduction in antioxidant capacity through the excessive production of reactive oxygen species and depletion of the anti-radical defence system following its metabolism in the liver, generating lipoperoxidation leading to the deterioration of liver tissue, the presence of these lesions leads to the destruction of hepatocytes by necrosis or apoptosis, which being destructured, the liver can no longer perform its functions normally, which explains the physiological disturbances of liver and serum biomarkers in the interior environment. ${ }^{89}$

The oral administration of $200 \mathrm{mg} / \mathrm{kg} /$ day of ethanolic extract of Rosmarinus officinalis (EER) for 90 days in ethanol intoxicated Wistar male rats (G4) restored the alcohol-related physiological disorder and significantly reduced liver parameters compared to the ethanol intoxicated batch (G2).

These results reveal a hepato-protective action of this extract against the hepatic functional alterations that were induced by ethylism.

Then the stabilization and preservation of the integrated intraand extracellular membranes of hepatocytes revealed by the anatomopathological examination showed negligible tissue damage in rats treated with the ethanolic extract of Rosmarinus officinalis (EER) which are characterized by a slight degree of steatosis and a discrete inflammation infiltrate, showing signs of improvement and preservation of liver tissue against alcohol toxicity manifested by fatty degeneration, inflammation and necrosis. Thus, revealing that rosemary has been able to protect structural integrity and restore structural disorders caused by alcohol by limiting histological changes in liver damage.

\section{CONCLUSION}

All in all, the ethanolic extract of Rosmarinus officinalis (EER) considerably inhibits the hepatic dysfunction induced by the harmful metabolism of ethyl alcohol as well as the oxidative damage resulting from its toxicity and confers a hepatocurative and hepatoprotective effect probably due to its richness in bioactive chemical compounds. Such as polyphenolics mainly rosmarinic acid and flavonoids contains an increased antioxidant activity and inhibition of lipid peroxidation.

Furthermore, these metabolites are known for other diverse biological properties that may play a paramount role in protecting the liver damaged particularly by alcohol. Contributing to provide an environment conducive to the mechanisms of liver regeneration at optimal levels allowing the recovery of liver mass to correct deficits in liver function by enhancing the total cellular antioxidant capacity and reducing the oxidation of macromolecules (lipids and protein) and the level of free radicals and reactive oxygen species (ROS) of malondialdehyde (MDA) in the liver tissue, thus preserving the liver tissue architecture and function.

It would be legitimate to deduce, as shown in our results, that the hepato-protective effect of the ethanolic extract of Rosmarinus officinalis against the complex hepatic toxicity induced by ethyl alcohol results originates from the synergy of its bioactive phyto-components endowed with multiple and diverse pharmacological properties that confer an optimal therapeutic intake for physiological and tissue lesions of the liver and slows down its evolution.

\section{ACKNOWLEDGEMENTS}

This work was sponsored with the Abdelhamid Ibn Badis University (a research project PRFU D00L01UN270120190001), Moulay Tahar University and University ULB Bruxelles.

\section{CONFLICTS OF INTEREST}

We wish to confirm that there are no known conflicts of interest associated with this publication.

\section{ABBREVIATIONS}

CAT: Catalase; DPPH: 2,2-Diphenyl-1-Picrylhydrazyl; $\mathrm{IC}_{50}$ : Inhibitory Concentration 50; EAG: Gallic Acid Equivalent; GSH-Px: glutathione peroxidase; HPLC/UV: High Performance Liquid Chromatography/ Ultraviolet; MDA: Malondialdehyde; EQ: Quercetin Equivalent; SOD: Superoxide dismutase.

\section{REFERENCES}

1. Vasiljevik T, Franks LN, Ford BM, Douglas JT, Prather PL, Fantegrossi WE, Prisinzano TE. Design, synthesis, and biological evaluation of aminoalkylindole derivatives as cannabinoid receptor ligands with potential for treatment of alcohol abuse. J Med Chem. 2013; 56(11): 4537-4550

2. Rehm J, Samokhvalov AV, Shield KD. Global burden of alcoholic liver diseases. J Hepatol. 2013; 59 (1): 160-168

3. Edenberg HJ, Foroud T. Genetics and alcoholism. Nat. Rev. Gastroenterol. Hepatol. 2013; 10 (8): 487-494.

4. Gao B, Bataller R. Alcoholic liver disease: pathogenesis and new therapeutic targets. Gastroenterology. 2011; 141 (5): 1572-1585.

5. Seth D, Hogg PJ, Gorrell MD, McCaughan GW, Haber PS. Direct effects of alcohol on hepatic fibrinolytic balance: implications for alcoholic liver disease. J Hepatol. 2008; 48 (4): 614-627.

6. Fregozoa CS, Beltránb MLM, Sotoc MEF, Vegaa MIP, Zárate CB Ruiz LH. Expression of NMDA receptor subunits in rat prefrontal cortex with CCL4-induced hepatic damage after a treatment with Rosmarinus officinalis L. Neurologia. 2012; 27 (5): 261-267.

7. Shirpoor A, Salami S, Khadem-Ansari MH, Heshmatian B. Ilkhanizadeh, Long term ethanol consumption initiates atherosclerosis in rat aorta through inflammatory stress and endothelial dysfunction. Vascul Pharmacol. 2012; 57(2-4): 72-77.

8. Shirpoor A, Nemati S, Ansari MH, Ilkhanizadeh B. The protective effect of vitamin $E$ against prenatal and early postnatal ethanol treatment-induced heart abnormality in rats: a 3-month follow-up study. Int Immunopharmacol. 2015; 26(1): 72-79.

9. Tian H, Ye X, Hou X, Yang $X$, Yang J, Wu C. SVCT2, a potential therapeutic target, protects against oxidative stress during ethanolinduced neurotoxicity via JNK/p38 MAPKs, NF-kB and miRNA125a5p, Free Radic. Biol Med. 2016; 96: 362-373.

10. Görg B, Qvartskhava N, Bidmon HJ, Palomero-Gallagher N, Kircheis G, Zilles K, Haussinger D. Oxidative stress markers in the brain of patients with cirrhosis and hepatic encephalopathy. Hepatology. 2010; 52(1): 256-265.

11. Logan-Garbisch T, Bortolazzo A, Luu P, Ford A, Do D, Khodabakhshi P, French $\mathrm{RL}$. Developmental ethanol exposure leads to dysregulation of lipid metabolism and oxidative stress in Drosophila. G3: Genes, Genomes, Genetics. 2015; 5(1): 49-59.

12. Bayliak MM, Shmihel HV, Lylyk MP, Storey KB, Lushchak VI. Alphaketoglutarate reduces ethanol toxicity in Drosophila melanogaster by enhancing alcohol dehydrogenase activity and antioxidant capacity. Alcohol. 2016; 55: 23-33.

13. Miller-Pinsler L, Wells PG. Embryonic catalase protects against ethanol embryopathies in acatalasemic mice and transgenic human catalase-expressing mice in embryo culture. Toxicol Appl Pharmacol. $2015 ; 15 ; 287(3): 232-9$.

14. Cederbaum Al, Lu Y, Wu D. Role of oxidative stress in alcoholinduced liver injury. Archives of toxicology. 2009; 83(6): 519-548. 
15. Lushchak VI. Free radicals, reactive oxygen species, oxidative stress and its classification. Chemico-biological interactions. 2014; 224 : 164-175.

16. Teixeira-Clerc F. Effets hépatiques de l'alcoolHepatic effects of alcohol. Cahiers de Nutrition et de Diététique. 2015; 50 (2): 94-102.

17. Attignon $\mathrm{E}$, Rouach $\mathrm{H}$. Molecular bases of ethanol toxicity. Etienne Blanc. Cahiers de nutrition et de diététique, biochimie. 2015; 50: 84-93.

18. Shirpoor A, Salami S, Khadem-Ansari MH, Minassian S, Yegiazarian M. Protective effect of vitamin $E$ against ethanol-induced hyperhomocysteinemia, DNA damage, and atrophy in the developing male rat brain. Alcohol Clin Exp Res. 2009; 33(7): 1181-6.

19. Shirpoor A, Norouzi L, Khadem Ansari MH, Ilkhanizadeh B, Gharaaghaji R. Vasoprotective effect of vitamin E: Rescue of ethanolinduced atherosclerosis and inflammatory stress in rat vascular wall. International Immunopharmacology. 2013; 16(4): 498-504.

20. Garg G, Adams JD. Treatment of neuropathic pain with plant medicines. Chin J Integr Med. 2012; 18(8): 565-570.

21. Nânci CD. Oliveira D, Sarmento MS, Nunes EA, Porto CM, Rosa DP, Bona SR, Rodrigues G, Marroni NP, Pereira P, Picada JN, Ferraz ABF, Thiesen FV, Silva JD. Rosmarinic acid as a protective agent against genotoxicity of ethanol in mice. Food and Chemical Toxicology. 2012; 50: $1208-1214$

22. Moon JK, Shibamoto T. Antioxidant assays for plant and food components. J Agric Food Chem. 2009; 57(5): 1655-1666.

23. Georgiev V, Ananga A, Tsolova V. Recent advances and uses of grape flavonoids as nutraceuticals. Nutrients. 2014; 6(1): 391-415.

24. Kurek-Gorecka A, Rzepecka-Stojko A, Gorecki M, Stojko J, Sosada M, Swierczek-Zieba G. Structure and Antioxidant Activity of Polyphenols Derived from Propolis. Molecules. 2014; 19(1): 78-101.

25. Chen HL, Lan XZ, Wu YY, Ou YW, Chen TC, Wu WT. The antioxidant activity and nitric oxide production of extracts obtained from the leaves of Chenopodium quinoa Willd. Biomedicine (Taipei). 2017; 7(4): 24.

26. Al-Sereiti MR, Abu-Amer KM, Sen P. Pharmacology of rosemary (Rosmarinus officinalis Linn) and its therapeutic potentials. Indian $\mathrm{J}$ Exp Biol. 1999; 37(2): 124-130.

27. Ahmed HM, Babakir-Mina M. Investigation of rosemary herbal extracts (Rosmarinus officinalis) and their potential effects on immunity. Phytotherapy Research. 2020; 34(8): 1829-1837.

28. Nieto G, Ros G, Castillo J. Antioxidant and Antimicrobial Properties of Rosemary (Rosmarinus officinalis, L.). A Review, Medicines. 2018; 5(3): 98.

29. Jafari-Sales A, Pashazadeh M. Study of chemical composition and antimicrobial properties of Rosemary (Rosmarinus officinalis) essential oil on Staphylococcus aureus and Escherichia coli in vitro. International Journal of Life Sciences and Biotechnology. 2020; 3(1): 62 - 69 .

30. Fahim FA, Esmat AY, Fadel HM, Hassan KF. Allied studies on the effect of Rosmarinus officinalis $L$. on experimental hepatotoxity and mutagenesis. Int J Food Sci Nutr. 1999; 50(6): 413-427.

31. Allegra A, Tonacci A, Pioggia G, Musolino C, Gangemi S. Anticancer Activity of Rosmarinus officinalis L.: Mechanisms of Action and Therapeutic Potentials. Nutrients. 2020; 12(6): 1739.

32. Machado DG, Cunha VB, Neis GO, Balen A, Colla LE, Bettio A, Oliveira FL, Pazini FL, Dalmarco JB, Simionatto EL, Pizzolatti MG, Rodrigues ALS. Antidepressant-like effects of fractions, essential oil, carnosol and betulinic acid isolated from Rosmarinus officinalis $\mathrm{L}$. Food Chem. 2013; 136(2): 999-1005.

33. Hassani FV, Shirani K, Hosseinzadeh H. Rosemary (Rosmarinus officinalis) as a potential therapeutic plant in metabolic syndrome: a review. Naunyn Schmiede Arch Pharm. 2016; 389(9):931-41.
34. Ali A, Oon CC, Chua BL, Figiel A, Chong CH, Wojdylo A, Turkiewics IP, Szumny A, Lyczko J. Volatile and polyphenol composition, anti-oxidant, anti-diabetic and anti-aging properties, and drying kinetics as affected by convective and hybrid vacuum microwave drying of Rosmarinus officinalis L. Industrial Crops and Products. 2020; 151: 112463.

35. Gonzalez-Trujano ME, Pena El, Martinez AL, Moreno J, GuevaraFefer P, Deciga- Campos M, Lopez-Munoz FJ. Evaluation of the antinociceptive effect of Rosmarinus officinalis $L$. using three different experimental models in rodents. J Ethnopharmacol. 2007; 111(3): 476-482.

36. Martínez AL, González-Trujano ME, Pellicer F, López-Muñoz FJ, Navarrete A. Antinociceptive effect and GC/MS analysis of Rosmarinus officinalis $L$. essential oil from its aerial parts. Planta Med. 2009; 75(5): 508-511.

37. Abdel-Hameed ES. Total phenolic contents and free radical scavenging activity of certain Egyptian Ficus species leaf samples. Food Chem. 2009; 114(4):1271-1277.

38. Woisky RG, Salatino A. Analysis of Propolis: Some Parameters and Procedures for Chemical Quality Control. Journal of Apicultural Research. 1998; 37(2): 99-105.

39. Tang CC, Huang HP, Lee YJ, Tang YH, Wang CJ. Hepatoprotective effect of mulberry water extracts on ethanol-induced liver injury via anti-inflammation and inhibition of lipogenesis in C57BL/6J mice. Food and Chemical Toxicology. 2013; 62: 786-796.

40. Chaa S, Boufadi YM, Keddari S, Benchaib AH, Soubhye J, Van Antwerpen P, Riazi A. Chemical composition of propolis extract and its effects on epirubicin-induced hepatotoxicity in rats. Revista Brasileira de Farmacognosia. 2019; 29(3): 294-300.

41. Elstner EF, Youngman RJ, Obwald W. Superoxyde dismutase in methods of enzymatic analysis. 3rd Ed. Bergmeyer $\mathrm{H}$, Editor. Method of Enzymatic analysis. Weinheim: Verlag Chemie. GmbH; 1983.

42. Lück H. Catalase. 2nd Ed. In: Bergmeyer HU, Editor. Methods of Enzymatic Analysis. Academic Press, London; 1965.

43. Aebi H. Catalase. 2nd Ed. In: Bergmeyer HU, Gawehn, K, Editors. Methods of enzymatic analysis V2: Verlag Chemie: Academic Press, Weinheim; 1974.

44. Paglia DE, Valentine WN. Studies on the quantitative and qualitative characterization of erythrocyte glutathione peroxydase. $J$ of Laboratory and Clin Med. 1967; 70: 158-169.

45. Yagi K. A simple fluorometric assay for lipoperoxide in blood plasma. Biochem Med. 1976; 15 (2): 212-216.

46. Drury RA, Wallington EA. Carleton's Histological Techniques, 5th Ed. Oxford University Press, New York, 1967, pp. 195.

47. Amaral GP, De Carvalho NR, Barcelos RP, Dobrachinski F, Portella RDL, Da Silva MH, Lugokenski TH, Dias GRM, Da Luz SCA, Boligon $A A$, Athayde ML, Villetti MA, Antunes Soares FA, Fachinetto R. Protective action of ethanolic extract of Rosmarinus officinalis $L$. in gastric ulcer prevention induced by ethanol in rats. Food Chem Toxicol. 2013; 55: 48-55.

48. Menaceur F. Composition chimique et activité biologique des huiles essentielles et extraits du romarin. Diplôme de magister. École nationale supérieur agronomique El-Harrach Alger. 2011

49. Stephanovits Banyai E, Tulok MH, Hegedus A, Renner C, Szololosi Varga L. Antioxidant effect of various Rosemary (Rosmarinus Officinalis L.) clones. Acta Biologica Szegediensis. 2003; 47(1-4): 111-113.

50. Tavassoli S, Djomeh E. Total Phenols, Antioxidant Potentia andAntimicrobial Activity of Methanol Extract of Rosemary (Rosmarinus officinalisL.). Global Veterinaria. 2011; 338(4):337-341.

51. Erkan N, Ayranci G, Ayranci E. Antioxidant activities of rosemary (Rosmarinus Officinalis L.). Extract, blackseed (Nigella sativa L.) essential oil,carnosic acid, rosmarinic acid and sesamol. Food Chem. 2008; 110(1): 76-82. 
52. Ho SC, Tsai TH, Tsai PJ, Lin CC. Protective capacities of certain spices against peroxynitrite-mediated biomolecular damage. Food and Chemical Toxicology. 2008; 46(3):920-928.

53. Tsai $P$, Tsai T, Ho S. In vitro inhibitory effects of rosemary extracts on growth and glucosyltransferase activity of Streptococcus sobrinus. Food Chem. 2007; 105: 311-316.

54. Falleh H, Ksouri R, Chaieb K, Karray-Bouraoui N, Trabelsi N, Boulaaba M, Abdelly C. Phenolic composition of Cynara cardunculus L. organs, and their biological activities. C. R. Biologies. 2008; 331: 372-379.

55. Podsedek A. Natural antioxidants and antioxidant capacity of Brassica vegetables: A review. LWT Food Sci Technol. 2007; 40:1-11.

56. Wang H, Provan GJ, Helliwell K. Determination of rosmarinic acid and caffeic acid in aromatic herbs by HPLC. Food Chemistry. 2004; 87(2): 307-311

57. Koşar M, Dorman HJD, Hiltunen R. Effect of an acid treatment on the phytochemical and antioxidant characteristics of extracts from selected Lamiaceae species. Food chemistry. 2005; $91(3)$ : 525-533.

58. Durling NE, Catchpole OJ, Grey JB, Webby RF, Mitchell KA, Foo LY, Perry NB. Extraction of phenolics and essential oil from dried sage (Salvia officinalis) using ethanol-water mixtures. Food chemistry. 2007; $101(4):$ 1417-1424.

59. Djeridane A, Yous M, Nadjemi B, Boutassouna D, Stocker P, Vidal N. Antioxidant activity of some Algerian medicinal plants extracts containing phenolic compounds. Food Chem. 2006; 97: 654-660.

60. Dent M, Dragović-Uzelac V, Penić M, Bosiljkov T, Levaj B. The effect of extraction solvents, temperature and time on the composition and mass fraction of polyphenols in Dalmatian wild sage (Salvia officinalis L.) extracts. Food technology and biotechnology. 2013; 51(1): 84-91.

61. Tura D, Robards K. Sample handling strategies for the determination of biophenols in food and plants. Journal of chromatography A. 2002; 975(1): 71-93.

62. Peng Y, Yuan J, Liu F, Ye J. Determination of active components in rosemary bycapillaryelectrophoresis with electrochemical detection. J Pharmaceutical and Biomedical Analysis. 2005; 39(3-4): 431-437.

63. Almela L, Sanchez-Munoz B, Fernandez-Lopez JA, Roca MJ, Rabe V. Liquidchromatograpic- mass spectrometric analysis of phenolics and free radical scavenging activity of rosemary extract from different raw material. J Chromatography A. 2006; 1120(1-2): 221-229.

64. Dorman HJD, Peltoketo A, Hiltunen R, Tikkanen MJ. Characterisation of the antioxidant properties of de-odourised aqueous extracts from selected Lamiaceaeherbs. Food Chem. 2003; 83(2): 255-262.

65. Cosio MS, Buratti S, Mannino S, Benedetti S. Use of an electrochemical method to evaluate the antioxidant activity of herb extracts from the Labiatae family. Food chemistry. 2006; 97(4): 725-731.

66. Bruneton J. Pharmacognosie, phytochimie, plantes médicinales. 3ème Ed, Lavoisier, Paris; 1999.

67. Caillet S, Shareck F, Lacroix M. Effect of gamma radiation and oregano essential oil on murein and ATP concentration of Escherichia coli O157: H7. J food protection. 2005; 68(12): 2571-2579.

68. Caillet S, Salmiéri S, Lacroix M. Evaluation of free radical-scavenging properties of commercial grape phenol extracts by a fast colorimetric method. Food Chemistry. 2006; 95(1): 1-8.

69. Wojdyło A, Oszmian'ski J, Czemerys R. Antioxidant activity and phenolic compound in 32 selected herbs. Food Chemistry. 2007; 105(945): 940-949

70. Vasdev SC, Subrahamany D, Charkravarti RN, Wahi PL. Effect of chronic ethanol-feeding on the major lipids of red blood cells, liver heart of rhesus monkey. 1974; 369(3): 323-330.

71. Bergheim I, Guo L, Davis MA, Lambert JC, Beier JI, Duveau I, Luyendyk JP, Roth RA, Arteel GE. Metformin prevents alcoholinduced liver injury in the mouse: critical role of plasminogen activator inhibitor-1. Gastroenterology. 2006; 130(7): 2099-2112.
72. Longo MC, Lokan RJ, White JM. The relationship between blood benzodiazepine concentration and vehicle crash culpability. J Traffic Med. 2001; 29(1-2): 36-43.

73. Sotelo-Félix JI, Martinez-Fong D, Muriel P, Santillán RL, Castillo D, Yahuaca P. Evaluation of the effectiveness of Rosmarinus officinalis (Lamiaceae) in thealleviation of carbon tetrachloride-induced acute hepatotoxicity in the rat.Journal of Ethnopharmacology. 2002; 81(2): 145-154.

74. Bragagnolo N, Danielsen B, Skibsted LH. Rosemary as antioxidant in pressure processed chicken during subsequent cooking as evaluated by electron spin resonance spectroscopy. Innovative Food Science and Emerging Technologies. 2007; 8: 24-29.

75. Albu S, Joyce E, Paniwnyk L, Lorimer JP, Mason TJ. Potential for the use of ultrasound in the extraction of antioxidants from Rosmarinus officinalis for the food and pharmaceutical industry. Ultrasonics Sonochemistry. 2004; 11(3-4): 261-265.

76. Debersac P, Heydel JM, Amiot MJ, Goudonnet H, Artur Y, Suschetet $\mathrm{M}$, Siess $\mathrm{MH}$. Induction of cytochrome P450 and/or detoxication enzymes by various extracts of rosemary: description of specific patterns. Food and Chemical Toxicology. 2001; 39(9): 907-918.

77. Hur YG, Yun Y, Won J. Rosmarinic acid induces p56lck-dependent apoptosis in Jurkat and peripheralT cells via mitochondrial pathway independent fromFas/Fas ligand interaction. J. Immunol. 2004; 172(1): 79-87.

78. Vermeulen NPE, Bessems JGM, Van de Streat R. Molecular aspects of paracetamol induced hepatotoxicityand its mechanism-based prevention. Drug Metab. Rev. 1992; 24(3): 367-407.

79. Uzun H, Simsek G, Aydin S, Unal E, Karter Y, Yelmen NK, Kaya S. Potential effects of L-NAME on alcohol-induced oxidative stress. World Journal of Gastroenterology. 2005; 11(4): 600-604.

80. I.P.C.S, The International Programme on Chemical Safety. Environmental health criteria (208). Carbon tetrachloride. World Health Organization, Geneva; 1999.

81. Jaiswal AK. Antioxidant response element. Biochemical Pharmacology. 1994; 48(3): 439-444.

82. Primiano T, Sutter T, Kensler TW. Antioxidant-induciblegenes. Advances in Pharmacology. 1997; 38: 293-328.

83. Kumar KB, Kuttan R. Chemoprotective activity of anextract of Phyllanthus amarus against cyclophosphamide induced toxicity in mice. Phytomedicine. 2005; 12(6-7): 494-500.

84. Khatoon S, Imran M. Studies on the plant biodiversity of Hub river estuary [Pakistan]. International Journal of Biology and Biotechnology (Pakistan). 2006; 2(4): 853-861.

85. Aruoma Ol. Free radicals, oxidative stress, and antioxidants in human health and disease. Journal of the American oil chemists' society. 1998; 75(2): 199-212.

86. Uchiyama M, Mihara M. Determination of malonaldehyde precursor in tissues by thiobarbituric acid test. Analytical biochemistry. 1978; 86(1): 271-278

87. Emerit J, Braquet M, Congy F, Clavei JP. Superoxyde dismutase erythrocytaire chez l'aicoolique chronique avec 16-sions hépatiques. Presse Med. 1987; 13:1277-1278.

88. Nieto N. A systems biology approach for understanding the collagen regulatory network in alcoholic liver disease. Liver International. 2012; 32(2): 189-198.

89. Sha L, Hor-Yue T, Ning W, Zhang-Jin Z, Lixing L, Chi-Woon W and Yibin $\mathrm{F}$. The role of oxidative stress and antioxidants in liver diseases. Int J Mol Sci. 2015; 16(11): 26087-26124. 


\section{GRAPHICAL ABSTRACT}

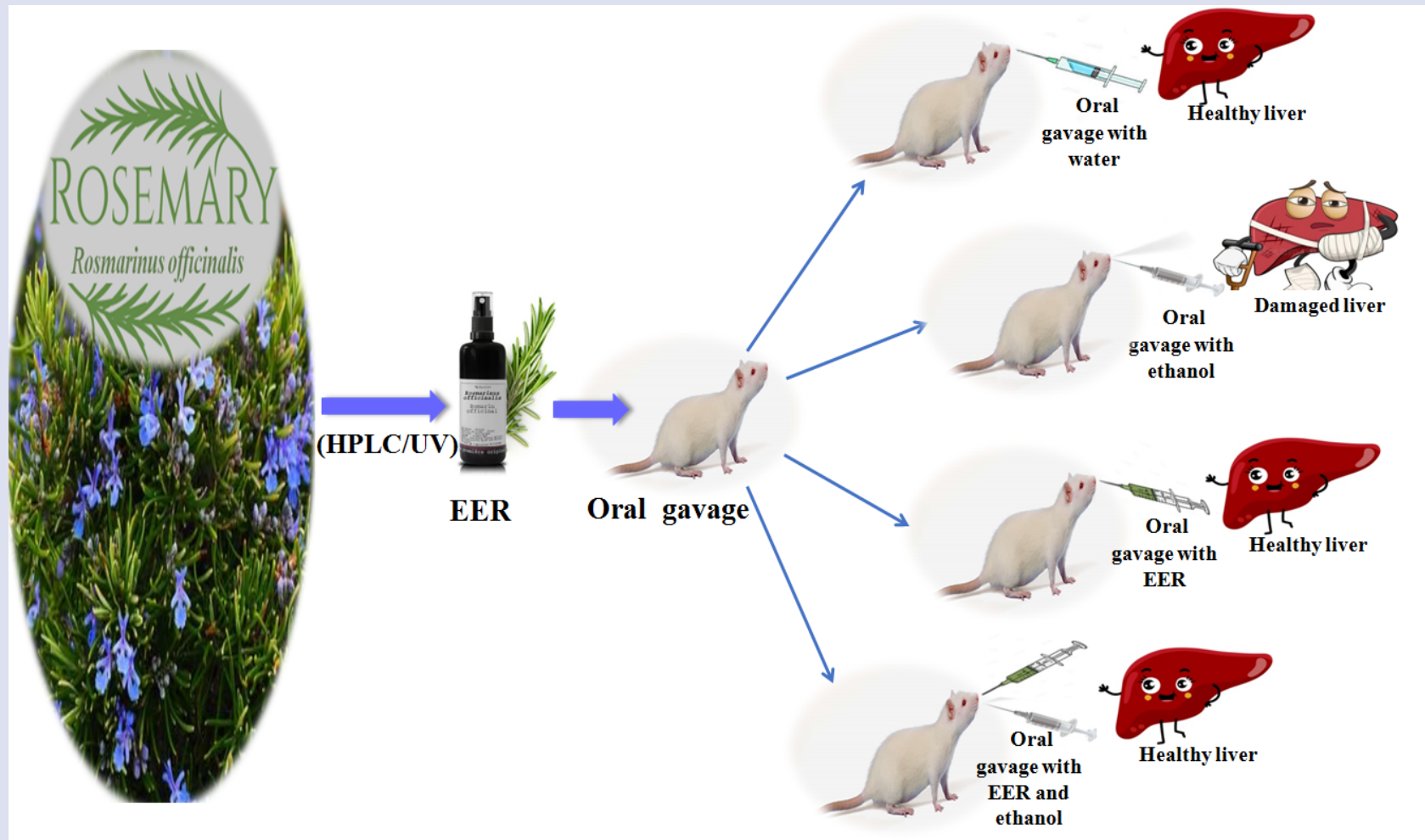

\section{ABOUT AUTHORS}

Pr Mokhtaria Yasmina BOUFADI, head of the research team "Biomolecules and toxicity", at the Laboratory of Bioeconomics, Food Safety and Health LBFSH (University of Mostaganem, Algeria), born on June 20th, 1982, in Saida (Algeria). A doctorate in Human Nutrition in 2014 from the Abdelhamid Ibn Badis Mostaganem University (Algeria). In 2009, Dr Boufadi joined the Abdelhamid Ibn Badis University as well as a research-teacher, she joined the administration as well as head of Research-Training at the Ministry of Higher Education and Scientific Research (MESRS, Algeria).

His research team has developed research on natural substances and their applications in many consumer products.

Cite this article: AOUAD RF, BOUFADI MY, ADLI DEH, MOULAI-HACENE F, KAHLOULA K, SLIMANI M. Chemical Composition and Protective Effect of Rosmarinus officinalis on Alcohol-Induced Serum Hepatic Changes and Liver Injury in Male Rats. Pharmacogn J. $2021 ; 13(5):$ 1205-1215. 